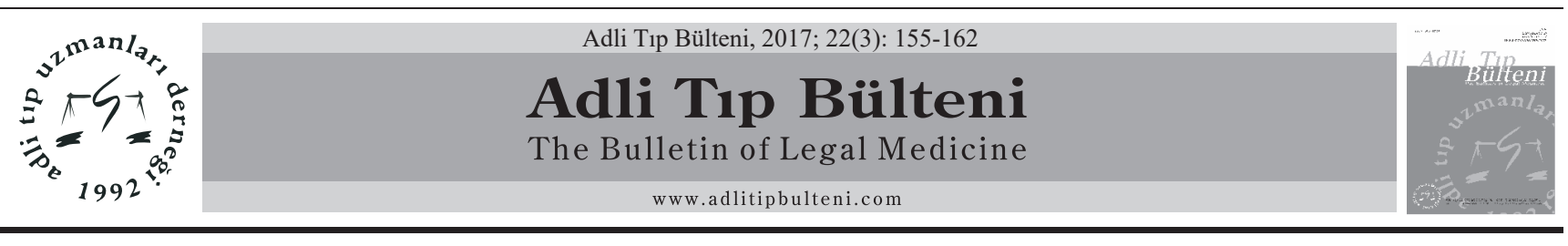

\title{
Suça Sürüklenen Çocuklar ile İkamet Yeri, Suç Yeri ve Suç Türü İlişkisi: İstanbul Adliyesi 2. Çocuk Mahkemesi Örneklemi
}

\author{
The Relationship of Children Driven to Crime with Place of Residence, Crime Scene \\ and Type of Crime: The Sample of 2nd Juvenile Court of İstanbul Court House
}

\author{
Zeynep Gülüm, Zeynep Pınar Cohen, Yusuf Tunç Demircan \\ İstanbul Üniversitesi, Adli Tıp Enstitüsü Sosyal Bilimler Anabilim Dal, İstanbul
}

\begin{abstract}
Özet
Amaç: Çocukların suça sürüklenmesinde çevresel nedenlerin, bireysel nedenlerden daha ön planda olmasına bağlı olarak çocukların suça sürüklenmesiyle ilgili yapılan çalışmalarda mekân araştırmaları önem kazanmıştır. Bu çalışmada suça sürüklenmenin yoğun olduğu yerleşim birimlerini tespit etmek, bu mahallelerde hangi suç tipine daha çok yönelim olduğunu ve çocukların yaşadığı yer ile suça sürüklendiği yer arasındaki ilişkiyi ortaya koymak amaçlanmaktadır. Bu çalışmadan elde edilecek bulgular ile suça sürüklenmenin yoğun olarak yaşandığı mahallelerde yapılması gereken önleme çalışmalarına ıșık tutmak hedeflenmektedir.
\end{abstract}

Gereç ve Yöntem: İstanbul Adliyesi'nde görev yapan yedi çocuk mahkemesinden biri olan 2. Çocuk Mahkemesi'nde 2015 yılında sonuçlandırılmış 520 gerekçeli karardan ulaşılan 668 suça sürüklenen çocuk incelenmiştir. Verilerin frekans ve yüzdelik dağllımının tespiti için betimleyici analiz, kategorik değişkenlerin birbiriyle ilişkisini değerlendirmek için ki kare testi kullanılmıştır.

Bulgular: Olguların \%90'ı erkek olup, \%76.5'i, 15-18 yaş aralığındadır. Suç türlerinin dağılımına bakıldığında mala karşı suçların (\%62) daha yoğunluklu olduğu görülmektedir. Suç yeri dağılımına bakıldığında, Fatih (\%27.5), Şişli (\%19.3) ve Beyoğlu (\%15.3) ilçelerinin önde geldiği belirlenmiştir. Suça sürüklenen çocukların ikamet ettikleri

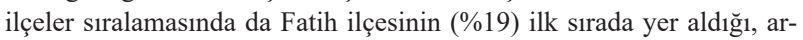
dından Beyoğlu (\%13.5), Kâğıthane (\%11.4) ve Eyüp (\%9.7) ilçelerinin geldiği saptanmıștır. Mahalle bazında inceleme yapıldığında, Beyoğlu İlçesine bağlı İstiklal Mahallesi birinci sırada gelmektedir. Yapılan ki kare analizlerinde suç türü ile suç yerinin, ikamet yeri ile suç yerinin, ikamet yeri ile suç türünün istatistiksel olarak anlamlı şekilde birbirinden farklılaştığı görülmüştür.

Sonuç: Çalışmada suç yeri, suç türü ve ikamet yerinin beraber değerlendirilmesi sonucu İstanbul Adliyesi yargı çevresinde yer alan Fatih İlçesinin her suç türü için çocukların hem ikamet ettikleri hem de suça sürüklendikleri yer olarak en ön sırada yer aldığı görülmektedir. Yaşanılan mahalle düzeyinde incelendiğinde bazı mahallelerde bilhassa tek bir suç türünün ön plana çıktığı tespit edilmiştir.

Anahtar Kelimeler: Suça Sürüklenen Çocuklar; İkamet Yeri; Suç Yeri; Suç Türü; Suç Önleme.

\begin{abstract}
Objective: Studies of children's residences has gained importance depending on the fact that environmental risk factors are more significant than individual risk factors in juvenile delinquency. This research aims to determine the settlements where children intensively driven to crime, identify typical type of crime in these neighborhoods and reveal the relationship between the places where the child is living and driven to crime. With the results of this study, it is aimed to shed light on the prevention studies that must be conducted in the neighborhoods where children intensively driven to crime.
\end{abstract}

Materials and Methods: In this study, 520 justified decisions, finalized in 2015 about 668 children driven to crime, that were reached from the second juvenile court of İstanbul Courthouse were examined. Descriptive analysis was used in order to determine frequency and percentage distribution of the data and chi-square test was used to assess the interrelatedness of categorical variables.

Results: Of subjects, $90 \%$ were male and $76.5 \%$ were in the $15-18$ age range. When the distribution of the type of crime was examined, crime against property $(62 \%)$ seemed to be more intensive. In terms of the distribution of crime scene, it was observed that Fatih (27.5\%), Şişli (19.3\%) and Beyoğlu (15.3\%) districts come forward. In the sequence of districts where children driven to crime resided Fatih (19\%) came in the first place again, afterwards Beyoğlu (13.5\%), Kağıthane (11.4\%) and Eyüp (9.7\%) districts came. Nevertheless, when examined on the basis of the neighborhood, İstiklal Neighborhood, which located in Beyoğlu district, came first. By the result of chi-square tests, it was observed that the relations between type of crime and crime scene, place of residence and crime scene, type of crime and place of residence were statistically significant.

Conclusion: By assessing crime scene, type of crime and place of residence together, the study showed that Fatih district came first at all of these variables. When examined at the level of residential neighborhood, it was revealed that in some neighborhoods, a particular type of crime has been specialized.

Keywords: Children Driven to Crime; Place of Residence; Crime Scene; Type of Crime; Crime Prevention.
Sorumlu Yazar: Zeynep Gülüm

İstanbul Üniversitesi, Adli Tip Enstitüsü Sosyal Bilimler Anabilim Dal, İstanbul

E-mail: zeynepgulum@gmail.com

Geliş: 21.12.2016 Düzeltme: 23.02.2017 Kabul: 10.07.2017

\section{Giriş}

Çocukların, özel gereksinimleri olan bireyler olduğu fikrinden hareketle "çocukların suçluluğu" kavramını, yetişkin suçluluğu kavramından farklı algılamak ve onların suçla olan ilişkisinde, suça sürükleniyor oldukları 
gerçeğini benimsemek önemlidir $(1,2)$. Bu bakışla, suça sürüklenen çocukların birer fail değil aslında mağdur olduğu ve çocuğun çoğunlukla içinde yaşadığı çevre-toplum-kültürün bir ürünü olduğu düşüncesi önem kazanmaktadir $(3,4)$.

Suça sürüklenen çocuk (SSÇ) sayısı dünyanın birçok ülkesinde (5-8) olduğu gibi ülkemizde de artış göstermektedir (8-10). Türkiye İstatistik Kurumu (TÜİK) verilerine göre, 2011-2015 yılları arasında güvenlik birimine suça sürüklenme sebebi ile gelen veya getirilen çocuk sayısı her yıl için bir önceki yıla göre artmaktadır (11). Çocukların suça sürüklenmesi, hem çocuk bireyi hem tüm toplumu ve sağlıklı toplumsal işleyişi ileriye dönük olarak negatif bir şekilde etkileyen sonuçları itibariyle salt hukuki olmayan bir olgudur $(6,9,12)$.

Çocukların suça sürüklenmesi, tekil bir sebeple açıklanamaz; pek çok faktörün göz önünde bulundurulması gerekmektedir (8). Çocuğun kişilik özellikleri ve kalıtsal etkenler gibi bireysel özelliklerin yanı sıra anne-baba davranışları, aile özellikleri, akran grupları, ekonomik koşullar, kültürel normlar ve öğretiler gibi çevresel faktörler sayılabilir (4). Suça sürüklenmenin bireysel ve çevresel nedenlerin etkileşiminin bir sonucu olduğu fakat yine de, çevresel nedenlerin görece daha etkili olduğu belirtilmektedir (8). Çocuğun çevresi, en yakınındaki ailesinden başlayarak, mahalle, okul, arkadaş grupları, yakın yerleşimler olmak üzere çeşitlendirilebilir (9).

Çevresel faktörlerin en önemlilerinden biri kentleşmedir. Türkiye'de çocukların suça sürüklenmesi (suç yeri) kentlerde yoğunlaşmakta ve suça sürüklenen çocukların çok büyük bir bölümü (\%93'ü) kentlerde ikamet etmektedir (2). Kentleşme süreci, kişilerin yaşam tarzlarında ve kişilerarası ilişkilerde radikal değişikliklere neden olmaktadır (13). Türkiye'de son 50-60 yılda kırsal alandan kentlere ve her bölgeden ülkenin Batı'sına doğru yoğun iç göç yaşanmaktadır (2). İç göç, çoğu zaman, gecekondulaşma, kentsel hizmetlerin aksaması, işsizlik, göç edenlerin topluma uyumsuzluğu, şehir kültürüne yabancılık ve kültürlerarası çatışma gibi sosyal sorunları da beraberinde getirmektedir (14). Özellikle düzensiz göçlerin yaşandığı ve iyi şehir planlamasının olmadığı yerlerde daha derin sorunlar ortaya çıkmaktadır $(4,13)$. Çocukların suça sürüklenmesinde plansız kentleşme, sanayileşme, alt yapı eksiklikleri, çevre kirliliği, arazi spekülasyonları gibi şehir planlaması ile problemlerin yanı sıra göç, kültürel sorunlar, psikolojik çatışmalar, sosyal ve ekonomik bunalımlar, toplumsal travmalar, işsizlik gibi sosyal yapıyı değiştiren sorunlar da önemli etkenler arasında sayılabilir $(3,13,15)$.

İç göç, hızlı ve plansız kentleşmenin bir sonucu olarak şehrin gelir dağılımından ve sosyal imkânlarından yeterli payı alamayan sosyoekonomik düzeyi düşük bölgeler oluşmaktadır (2). Bu tip bölgelerde ekonomik statünün düşüklügüñnden (16), eğitim imkânlarının kısıtlılığından, anne-babaların çalışması ile bağlantılı olarak aile içi eğitim ve rehberlik yoksunluğundan, çocukların çalıştırılmasından, sınıf farkı ve kültürel farklılıkların yarattığı çatışmalardan, olası dil problemlerinden, çocuk ve gençlerin hobilerini gerçekleştirme ve kültür sanat faaliyetlerine erişim zorluğunun meydana getirdiği boş zamanları uygun değerlendirme kısıtlılığından, firsat eşitsizliğinden bahsedilebilir. Sayılan faktörlerin hepsi, çocukların suça sürüklenmesinde etkili olabilecek risk faktörleridir $(4,8)$. Yapılan bir çalışmada suça sürüklenen çocukların, çoğunlukla şehrin sosyoekonomik düzeyi düşük bölgelerinde ikamet ettikleri gösterilmiştir (2).

Çocukların suça sürüklenmesinin önlenmesi, daha geniş anlamdaki suçluluğun önlenmesinin de özünü oluşturmaktadır $(9,16)$. Çocukların suça sürüklenmesinin önlenmesinde 4 ana stratejiden bahsedilmektedir: Kanuni yapt1rım, gelişimsel önleme, mahalli/yerel önleme ve durumsal önleme (17). Bu stratejilerin ilki olan kanuni yaptırım, ülkemizde suçla mücadele denildiğinde neredeyse tek başına uygulanan, suç oluştuktan sonra başvurulan cezalandırıcı ve caydırıcı yöntemlerdir. Bu yöntemlerin, ilerleyen zamanda suçu önleme konusunda yeterince başarılı olamad1ğ1 (17), suçu ancak geçici olarak önleyebileceği; hatta bazı durumlarda cezaevinde yeni taktiklerin öğrenilmesi yoluyla suçun artışına katkıda bulunduğu belirtilmektedir (18).

Çocukların suça sürüklenmesinde çevresel nedenlerin, bireysel nedenlerden daha ön planda olmasına bağ11 olarak çocukların suça sürüklenmesiyle ilgili yapılan çalışmalarda mekân araştırmaları önem kazanmıştır (19). $\mathrm{Bu}$ çalışmada suça sürüklenmenin yoğun olduğu yerleşim birimlerini tespit etmek, bu mahallelerde hangi suç tipine daha çok yönelim olduğunu ve çocukların yaşadığı yer ile suça sürüklendiği yer arasındaki ilişkiyi ortaya koymak amaçlanmaktadır. Suç her zaman bir 'yer'de işlenir ancak suça sürüklenen çocuklar düşünüldügüünde iyileştirme ve önleme çalışmalarının yapılması gereken yer, yaşanılan ve çocuk için hayatın öğrenildiği yer olmalıdır. Bu çalışmadan elde edilecek bulgular ile suça sürüklenmenin yoğun olarak yaşandığı mahallelerde bu duruma yol açan nedenlerin araştırılmasına ve önlemeye yönelik özelleşmiş iyileştirme programlarının sosyal çalışma kapsamında hangi bölgelere götürülmesi gerektiğine 1 şı tutmak hedeflenmektedir.

\section{Gereç ve Yöntem}

Araştırma kapsamında İstanbul Adliyesi 2. Çocuk Mahkemesi'nde 2015 yılının adli yıl bitimine (20 Temmuz) kadar sonuçlandırılmış olan gerekçeli kararlar incelenmiştir. Gerekçeli kararlardan yararlanılarak suça 
sürüklenen çocukların cinsiyeti, doğum tarihi, nüfusa kayıtlı olduğu il, ikametgâh adresi, suç türü, suç tarihi ve suç yerine (ilçe düzeyinde) ilişkin bilgiler toplanmıştır.

Araştırmada elde edilen veriler Statistical Package for Social Sciences (SPSS) 17 programında analiz edilmiştir. Verilerin frekans ve yüzdelik dağılımının tespiti için betimleyici analiz, kategorik değişkenlerin birbiriyle ilişkisini değerlendirmek için Ki kare testi kullanılmıştır.

\section{Bulgular}

Araştırmada 2015 yılında sonuçlandırılmış olan 520 dosyanın gerekçeli kararından 668 suça sürüklenen çocuğa (SSÇ) ilişkin veriler elde edilmiştir. Araştırmada SSÇ'ların \%10'u (n=67) kız, \%90'ı $(n=601)$ erkek olduğu belirlenmiştir. Çocukların \%23.5'inin $(n=157)$ 12-15 yaş aralığında, \%76.5'inin $(n=511) 15-18$ yaş aralığında olduğu saptanmıştır (Tablo 1).

SSÇ'ların nüfusa kayıtlı olduğu illere bakıldığında geniş bir dağılımın söz konusu olduğu görülebilmektedir. SSÇ'ların en çok İstanbul ( $n=78)$, Diyarbakır $(n=58)$, $\operatorname{Mardin}(n=41)$, Siirt $(n=30)$, Sivas $(n=27)$, Bitlis $(n=26)$, Batman $(n=24)$, Ağr1 $(n=22)$, Ordu $(n=21)$, Şanlıurfa $(n=21)$ illerine kayıtlı oldukları görülmektedir.

Bazı dosyalarda çocukların birden fazla suçtan aynı anda yargılandığı dikkate alındığında mevcut çalışmada yargılama yapılan toplam suç sayısı 901 olarak belirlenmiştir. Yargılama yapılan suç türlerinin dağılımına bakıldığında en başta hırsızlık türevi suçların geldiği $(n=304$, \%33.7); bunu takiben, uyuşturucularla ilgili suçların $(n=158, \% 17.5)$, mala zarar verme $(n=128, \% 14.2)$, dokunulmazlığı ihlal $(n=127, \% 14.1)$, yaralama $(n=108$, $\% 12)$, hakaret $(n=47, \% 5.2)$ ve tehdit ( $n=29, \% 3.2)$ suçlarının geldiği görülmektedir (Tablo 1). Hırsızlık türevi suçlar, mala zarar verme ve dokunulmazlığı ihlal suçları ile beraber "mal varlığına karşı suçlar" $(n=559, \% 62)$ ve uyuşturucularla ilgili suçlar, yaralama, hakaret ve tehdit suçları "kişiye karşı suçlar" $(n=342, \% 38)$ başlı̆̆ altında toplanarak olgular değerlendirilmiştir.

Suç yeri dağılımına bakıldığında, İstanbul Adliyesi yarg1 çevresinde yer alan Fatih $(n=184, \% 27.5)$, Şişli $(n=129, \% 19.3)$ ve Beyoğlu ( $n=102, \% 15.3)$ ilçelerinin önde geldikleri görülmektedir. Suça sürüklenen çocukların ikamet ettikleri ilçeler sıralamasında da Fatih ilçesinin $(n=127, \% 19)$ ilk sırada yer aldığı, ardından Beyoğlu ( $n=90, \% 13.5)$, Kâğıthane $(n=76, \% 11.4)$, Eyüp $(n=65$, \%9.7) ilçelerinin geldiği görülmektedir (Tablo 1).

İkamet edilen yer mahalle bazında incelendiğinde Beyoğlu İlçesine bağlı İstiklal Mahallesinin birinci sırada geldiği görülmüştür. Beyoğlu İlçesinde ikamet eden tüm SSÇ'ların \%20'si bu mahalledendir. İkinci sırada Fatih İlçesine bağlı Nişanca Mahallesi gelmektedir. Fatih İlçe-
Tablo 1. SSÇ’ların demografik özellikleri ve suç türü, suç yeri, ikamet yeri dağ 11 ımı

\begin{tabular}{|c|c|c|c|c|}
\hline Değişkenler & \multicolumn{2}{|l|}{ Frekans } & Yüzde & Toplam \\
\hline \multicolumn{5}{|l|}{ Cinsiyet } \\
\hline & $\mathrm{K}_{1 \mathrm{Z}}$ & 67 & 10,0 & \multirow{2}{*}{668} \\
\hline & Erkek & 601 & 90,0 & \\
\hline \multicolumn{5}{|l|}{ Yaş } \\
\hline & $12-15$ & 157 & 23,5 & \multirow{2}{*}{668} \\
\hline & $15-18$ & 511 & 76,5 & \\
\hline \multicolumn{5}{|c|}{ Nüfusa kayıtlı olduğu yer } \\
\hline & $\begin{array}{l}\text { Güneydoğu } \\
\text { Anadolu }\end{array}$ & 196 & 29,4 & \multirow{7}{*}{667} \\
\hline & Karadeniz & 137 & 20,5 & \\
\hline & Doğu Anadolu & 128 & 19,2 & \\
\hline & Marmara & 121 & 18,1 & \\
\hline & İç Anadolu & 49 & 7,3 & \\
\hline & Akdeniz & 31 & 4,6 & \\
\hline & Ege & 5 & 0,7 & \\
\hline \multicolumn{5}{|l|}{ Suç türü } \\
\hline & Hirsılik & 304 & 33,7 & \multirow{7}{*}{901} \\
\hline & Uyuşturucu & 158 & 17,5 & \\
\hline & $\begin{array}{l}\text { Mala zarar } \\
\text { verme }\end{array}$ & 128 & 14,2 & \\
\hline & Dokunulmazlığ & 127 & 14,1 & \\
\hline & Yaralama & 108 & 12,0 & \\
\hline & Hakaret & 47 & 5,2 & \\
\hline & Tehdit & 29 & 3,2 & \\
\hline \multicolumn{5}{|l|}{ Suç yeri } \\
\hline & Fatih & 184 & 27,5 & \multirow{9}{*}{668} \\
\hline & Şişli & 129 & 19,3 & \\
\hline & Beyoğlu & 102 & 15,3 & \\
\hline & Eyüp & 71 & 10,6 & \\
\hline & Kağıthane & 52 & 7,8 & \\
\hline & Bayrampaşa & 50 & 7,5 & \\
\hline & Beşiktaş & 40 & 6,0 & \\
\hline & Sarıyer & 39 & 5,8 & \\
\hline & Gaziosmanpaşa & 1 & 0,1 & \\
\hline \multicolumn{5}{|l|}{ İkamet yeri } \\
\hline & Fatih & 127 & 19,0 & \multirow{9}{*}{529} \\
\hline & Beyoğlu & 90 & 13,5 & \\
\hline & Kağıthane & 76 & 11,4 & \\
\hline & Eyüp & 65 & 9,7 & \\
\hline & Şişli & 46 & 6,9 & \\
\hline & Sarıyer & 42 & 6,3 & \\
\hline & Gaziosmanpaşa & 39 & 5,8 & \\
\hline & Esenler & 25 & 3,7 & \\
\hline & Sultangazi & 19 & 2,8 & \\
\hline & Diğer ilçeler & 94 & 14,1 & 623 \\
\hline & İstanbul diş1 & 45 & 6,7 & 668 \\
\hline
\end{tabular}


sinde ikamet eden tüm SSÇ'ların \%12.6's1 bu mahalledendir. Üçüncü sırada ise Eyüp İlçesine bağlı Defterdar Mahallesi yer almaktadır. Eyüp İlçesinde ikamet eden tüm SSÇ'ların \%23'ü bu mahalledendir. Bunların dışında dikkat çekici olarak Şişli İlçesine bağlı Kuştepe Mahalle-

Tablo 2. SSÇ’ların yoğunluklu olarak ikamet ettiği mahalleler

\begin{tabular}{|c|c|c|c|}
\hline \multicolumn{2}{|c|}{ İlçe Mahalle } & Frekans & Yüzde \\
\hline \multicolumn{2}{|l|}{ Fatih } & 127 & \\
\hline & Nişanca & 16 & 12,6 \\
\hline & Yavuz Sultan Selim & 13 & 10,2 \\
\hline & Aksaray & 8 & 6,3 \\
\hline & Muhsine Hatun & 8 & 6,3 \\
\hline & Zeyrek & 8 & 6,3 \\
\hline \multicolumn{2}{|l|}{ Beyoğlu } & 90 & \\
\hline & İstiklal & 18 & 20,0 \\
\hline & Yenişehir & 11 & 12,2 \\
\hline & Haciahmet & 8 & 8,9 \\
\hline \multicolumn{2}{|c|}{ Kağıthane } & 76 & \\
\hline & Sanayi & 10 & 13,2 \\
\hline & Telsizler & 10 & 13,2 \\
\hline \multicolumn{2}{|l|}{ Eyüp } & 65 & \\
\hline & Defterdar & 15 & 23,1 \\
\hline & Ağaçlı & 12 & 18,5 \\
\hline \multicolumn{2}{|l|}{ Şişli } & 46 & \\
\hline & Kuştepe & 12 & 26,1 \\
\hline & Yayla & 9 & 19,6 \\
\hline \multicolumn{2}{|l|}{ Sarıyer } & 42 & \\
\hline & Çayırbaşı & 12 & 28,6 \\
\hline & Cumhuriyet & 9 & 21,4 \\
\hline
\end{tabular}

sinde Şişli'de ikamet eden tüm SSÇ'ların \%26'sı ve Sarıyer İlçesine bağlı Cumhuriyet Mahallesinde Sarıer'de ikamet eden tüm SSÇ'ların \%28.6's1 yaşamını sürdürmektedir. SSÇ'ların yoğunluklu olarak ikamet ettiği mahalleler Tablo 2'de gösterilmiştir.

Suç yeri ve suç türü arasındaki ilişki incelendiğinde suç türleri açısından suç yerlerinin $[\mathrm{X}(42,901)=113.7$, $p<.001]$ birbirlerinden anlamlı olarak farklılaştığ 1 görülmüştür. Bu sonuca göre, hırsızlık türevi suçların yoğunluklu olarak Fatih $(n=92, \% 30.3)$, Şişli $(n=55, \% 18.1)$, Beyoğlu ( $n=38, \% 12.5)$, Eyüp $(n=30, \% 10)$ ve Beşiktaş $(n=29, \% 9.5)$ ilçelerinde meydana geldiği görülmüştür. Uyuşturucularla ilgili suçların yoğunluklu olarak Fatih $(n=43, \% 27.2)$, Şişli $(n=41, \% 26)$, Beyoğlu $(n=34$, $\% 21.5)$, Bayrampaşa $(n=12, \% 7.6)$ ilçelerinde meydana geldiği tespit edilmiştir. Mala zarar verme suçunun sırasiyla Fatih ( $n=34, \% 26.6)$, Eyüp $(n=20, \% 15.6)$, Beyoğlu $(n=18, \% 14.1)$, Şişli $(n=15, \% 11.7)$ ve Beşiktaş $(n=13$, \%10.2) ilçelerinde meydana geldiği ortaya konmuştur. Dokunulmazlığı ihlal suçunun yoğunluklu olarak Fatih $(n=36, \% 28.3)$, Şişli $(n=20, \% 15.7)$, Beyoğlu $(n=16$, \%12.6) ve Eyüp ( $n=15, \% 11.8)$ ilçelerinde meydana geldiği görülmüştür. Yaralama suçunun ise sırasıyla Fatih $(n=28, \% 26)$, Sarıyer $(n=18, \% 16.7)$, Beyoğlu $(n=17$, $\% 15.7)$ ve Eyüp ( $n=17, \% 15.7)$ ilçelerinde meydana geldiği tespit edilmiştir.

Suç yeri ve ikamet adresi arasındaki ilişki incelendiğinde, suç yeri ile ikamet yerinin birbirlerinden anlaml olarak farklılık gösterdiği $[\mathrm{X}(35,446)=888.2, p<.001]$ belirlenmiştir. Buna göre, SSÇ’ların diğer ilçelere nazaran kendi ikamet ettikleri ilçede daha fazla suça sürüklenmiş oldukları tespit edilmiştir. Suça sürüklenen çocuklardan Fatih ilçesinde ikamet edenlerin \%91.3'ünün olay yerinin kendi ilçe sınırlarında olduğu belirlenmiştir. Beyoğlu

Tablo 3. Suç yeri - İkamet yeri ilişkisi

\begin{tabular}{|l|l|c|c|c|c|c|c|c|c|c|}
\hline İkamet Yeri & & Fatih & Beyoğlu & Kağıthane & Eyüp & Şişli & Sarıer & Beşiktaş & Bayrampaşa & Toplam \\
\hline Fatih & $\mathrm{N}$ & 116 & 5 & 0 & 2 & 1 & 1 & 0 & 2 & 127 \\
\hline & $\%$ & 91.3 & 3.9 & 0 & 1.6 & 0.8 & 0.8 & 0 & 1.6 & \\
\hline Beyoğlu & $\mathrm{N}$ & 6 & 47 & 4 & 3 & 22 & 1 & 6 & 1 & 90 \\
\hline & $\%$ & 6.7 & 52.2 & 4.4 & 3.3 & 24.4 & 1.1 & 6.7 & 1.1 & \\
\hline Kağıthane & $\mathrm{N}$ & 3 & 5 & 35 & 1 & 23 & 3 & 6 & 0 & 76 \\
\hline & $\%$ & 3.9 & 6.6 & 46.1 & 1.3 & 30.3 & 3.9 & 7.9 & 0 & \\
\hline Eyüp & $\mathrm{N}$ & 5 & 8 & 3 & 36 & 8 & 0 & 3 & 2 & 65 \\
\hline & $\%$ & 7.7 & 12.3 & 4.6 & 55.4 & 12.3 & 0 & 4.6 & 3.1 & \\
\hline Şişli & $\mathrm{N}$ & 2 & 4 & 0 & 0 & 32 & 2 & 6 & 0 & 46 \\
\hline & $\%$ & 4.3 & 8.7 & 0 & 0 & 69.6 & 4.3 & 13 & 0 & \\
\hline Sarıyer & $\mathrm{N}$ & 0 & 3 & 1 & 0 & 11 & 24 & 3 & 0 & 42 \\
\hline & $\%$ & 0 & 7.1 & 2.4 & 0 & 26.2 & 57.1 & 7.1 & 0 & \\
\hline
\end{tabular}


(\%52.2), Eyüp (\%55.4), Sarıer (\%57.1) ve Şişli (\%69.6) ilçelerinde ikamet eden SSÇ’ların yarısından fazlasının kendi ilçe sınırları içerisinde suça sürüklenmiş olduğu, Kâğıthane (\%46.1) ilçesinde de bu oranın yarıya yakın olduğu görülmektedir (Tablo 3).

İkamet yeri ile suç türlerinin birbirlerinden anlam11 olarak farkl11ık gösterdiği $[\mathrm{X}(30,612)=87.8, p<.001]$ tespit edilmiştir. İkamet yeri ile suç türü arasındaki ilişki incelendiğinde hırsılılı türevi suçlara sürüklenmenin Fatih $(n=67, \% 22)$, Beyoğlu ( $n=61, \% 20.1)$ ve Kâğıthane $(n=30, \% 9.9)$ ilçelerinde ikamet eden SSÇ’larda daha yoğun olduğu görülmüştür. Uyuşturucularla ilgili suçlara sürüklenmenin Fatih $(n=30, \% 19)$, Kâğ tthane $(n=23$, \%14.6), Eyüp ( $n=14, \% 8.9)$ ve Şişli $(n=14, \% 8.9)$ ilçelerinde ikamet eden SSÇ'larda daha yoğun olduğu tespit edilmiştir. Mala zarar verme suçunun sırasıyla Beyoğlu $(n=26, \% 20.3)$, Fatih $(n=21, \% 16.4)$, Eyüp $(n=15$, \%11.7) ilçelerinde ikamet eden SSÇ’larda daha yoğun olduğu ortaya konmuştur. Dokunulmazlığ ihlal suçuna sürüklenmenin Fatih ( $n=27, \% 21.3)$, Beyoğlu $(n=17$, $\% 13.4)$ ve Eyüp $(n=12, \% 9.4)$ ilçelerinde ikamet eden
SSÇ’larda daha yoğun olduğu görülmüştür. Yaralama suçuna sürüklenmenin ise sirasıyla Fatih $(n=22, \% 20.4)$, Saryer $(n=18, \% 16.7)$ ve Eyüp $(n=15, \% 13.9)$ ilçelerinde ikamet eden SSÇ’larda daha yoğun olduğu tespit edilmiştir (Tablo 4).

Yaşanan mahalle ve suç türü arasındaki ilişki incelendiğinde, yaşanan mahalle ile suç türünün birbirlerinden anlamlı olarak farklılaştığ $[X(45,178)=72.6$, $p<.05]$ görülmüştür. Beyoğlu İlçesine bağlı İstiklal Mahallesinde ikamet eden SSÇ'ların tamamının $(n=18)$ hırsızlık türevi suçlara sürüklenmiş oldukları belirlenmiştir. Sarıyer İlçesine bağlı Cumhuriyet Mahallesinde ikamet eden SSÇ'ların tamamının $(n=9)$ ise yaralama suçuna sürüklenmiş oldukları tespit edilmiştir. Yine Sarıyer İlçesine bağlı Çayırbaşı Mahallesinde ikamet eden biri hariç diğer tüm SSÇ'ların $(n=11)$ hırsızlık türevi suçlara sürüklenmiş oldukları, bir SSÇ’un ise uyuşturucularla ilgili suçlara karışmış olduğu görülmüştür. Diğer mahallelerde ikamet eden SSÇ'ların ise farklı suç türlerinde dağılım gösterdikleri belirlenmiştir (Tablo 4).

Tablo 4. Suç türü - İkamet yeri ilişkisi

\begin{tabular}{|c|c|c|c|c|c|c|}
\hline İlçe & Mahalle & Hirsizlık & Uyuşturucu & Mala zarar verme & Yaralama & Dokunulmazlı̆̆ı ihlal \\
\hline \multicolumn{7}{|c|}{ Fatih } \\
\hline & Nişanca & 8 & 6 & 0 & 1 & 0 \\
\hline & $\begin{array}{l}\text { Yavuz Sultan } \\
\text { Selim }\end{array}$ & 6 & 2 & 3 & 4 & 4 \\
\hline & Aksaray & 2 & 3 & 1 & 3 & 0 \\
\hline & Muhsine Hatun & 6 & 2 & 1 & 0 & 1 \\
\hline & Zeyrek & 6 & 1 & 4 & 0 & 5 \\
\hline \multicolumn{7}{|c|}{ Beyoğlu } \\
\hline & İstiklal & 18 & 0 & 4 & 0 & 1 \\
\hline & Yenişehir & 8 & 2 & 2 & 1 & 3 \\
\hline & Haciahmet & 6 & 1 & 1 & 0 & 0 \\
\hline \multicolumn{7}{|c|}{ Kağıthane } \\
\hline & Sanayi & 4 & 1 & 0 & 3 & 1 \\
\hline & Telsizler & 5 & 5 & 3 & 0 & 2 \\
\hline \multicolumn{7}{|c|}{ Eyüp } \\
\hline & Defterdar & 8 & 6 & 3 & 0 & 5 \\
\hline & Ağaçl1 & 5 & 4 & 1 & 3 & 3 \\
\hline \multicolumn{7}{|c|}{ Şişli } \\
\hline & Kuştepe & 4 & 4 & 2 & 2 & 2 \\
\hline & Yayla & 5 & 3 & 1 & 0 & 1 \\
\hline \multicolumn{7}{|c|}{ Sariyer } \\
\hline & Çayırbaşı & 11 & 1 & 2 & 0 & 10 \\
\hline & Cumhuriyet & 0 & 0 & 0 & 9 & 0 \\
\hline
\end{tabular}




\section{Tartışma ve Sonuç}

Çocukların suça sürüklenmesinde çevresel nedenlerin, bireysel nedenlere göre daha etkili olduğu kabul edilmektedir $(8,9,19)$. Çalışmamızda, bu çevresel faktörlerden çocukların ikamet ettikleri yer, suça sürüklendikleri yer ve sürüklendikleri suç tipinin, suça sürüklenmeleri ile ilişkisi ortaya konulmaya çalışılmıştır.

Araştırmamızda yer alan çocukların yaş ve cinsiyet dağılımına bakıldığında erkeklerin ve $15-18$ yaş grubunun daha yoğun olduğu görülmektedir. Suça sürüklenen çocukların sosyodemografik özellikleri ile ilgili Türkiye'nin farklı bölgelerinde yapılmış olan çalışmalarda benzer sonuçların elde edildiği görülmüştür. Kütahya'da yapılan bir çalışmada SSÇ'ların \%93'ünün erkek ve \%66'sının 14-18 yaş arası olduğu (9), Adana'da yapılan bir başka çalışmada SSÇ'ların \%96'sının erkek ve \%78'inin 16-18 yaş arası olduğu (20), Hatay'da yapılan bir diğer çalışmada SSÇ'ların \%83'ünün erkek ve \%76'sının 15-18 yaş arası olduğu (21) bulunmuştur. Bu bağlamda, bulguların literatür ile uyumlu olduğu görülmektedir.

Suça sürüklenen çocukların nüfusa kayıtlı olduğu yerler incelendiğinde çocukların sadece \%12'sinin İstanbul nüfusuna kayıtlı oldukları anlaşılmaktadır. Mevcut çalışmaya benzer bir şekilde, İzmir Çocuk Mahkemesi'nin gerekçeli kararları incelenerek yapılan bir çalışmada (14) suça sürüklenen 3327 çocuğun \%35.5'inin İzmir nüfusuna kayıtlı oldukları görülmektedir. İstanbul'un İzmir'den daha yoğun göç alan bir kent olduğu dikkate alındığında rakamlar arasındaki farklılık anlaşılır olmaktadır.

Sosyoekonomik problemlerin ortaya çıkardığı bir diğer sonuç ise şiddet suçlarında görülen azalmaya karşın, mal varlığına karşı işlenen suçlarda ciddi artışlar görülmesidir (14). Suça sürüklenen çocukların sürüklendikleri suç tipine ilişkin yapılan çalışmalarda mal varlığına yönelik suçların ilk sırada yer aldığı görülmektedir. Adana'da suça sürüklenen çocuklarla ilgili yapılan bir çalışmada çocukların \%70'inin (22), İzmir'de yapılan bir başka çalışmada çocukların \%69'unun (14) mal varlığına karşı suçlara sürüklenmiş oldukları tespit edilmiştir. Araştırmanın bulguları da SSÇ'ların en çok mal varlığına karşı suçlara yöneldiğini göstermektedir.

Türkiye'de suça sürüklenen çocuklarla ilgili yapılan çalışmalar çoğunlukla SSÇ’ların sosyodemografik özellikleri üzerinde durmaktadır (21, 23-26). Yaptığımız çalışmada suç yeri, suç türü ve ikamet yerinin beraber değerlendirilmesi ile bu değişkenler arasındaki ilişkiler ortaya konmaya çalışılmıştır. Çalışmadan elde edilen bulgulardan yola çıkılarak İstanbul Adliyesi yargı çevresinde yer alan ilçelerden Fatih İlçesi, her suç türü için çocukların hem ikamet ettikleri hem de suça sürüklendikleri yer olarak en ön sırada yer almaktadır. Fatih İlçesi, eğitim seviyesinin düşük, genç nüfusun fazla, rekreatif amaçlı donatı alanlarının son derece yetersiz olduğu ve kötü yaşam standartları gibi özellikler sergileyen sosyal ve fiziksel köhneme bölgelerinin dikkat çektiği bir yerleşim birimidir. İlçenin bu özelliklerinin suç dağılımı ve yoğunluğunun fazlalığında etkili olduğu söylenebilir (18).

Yaşanılan mahalle düzeyinde incelendiğinde çocukların suça sürüklenmesinin en fazla yaşandığı yer Hacı Hüsrev Mahallesi olarak bilinen Beyoğlu İlçesine bağl1 İstiklal Mahallesi'dir. Burada ikamet eden SSÇ'larda sadece mal varlığına karşı suçlara yönelme olmasının, mahallenin sosyoekonomik özellikleri ile son derece ilişkili olduğu düşünülmektedir. Yüksek işsizlik oranları nedeniyle İstiklal mahallesinde yaşayan insanların yoksulluk ve yoksunluk seviyelerinin de yüksek olduğu; buna bağlı olarak çocukların eğitime erişme imkânlarının kısıtlı kaldığı bildirilmiştir. Eğitim eksikliği, meslek edinememe ve iş bilgisi ağının yetersiz oluşu ile birleşerek yasal iş firsatlarına erişilememesine, hukuk ve sosyal normların dışında seçeneklere kaymaya ve suç davranışının ortaya çıkmasına sebep olmaktadır. İstiklal mahallesi her ne kadar şehrin merkezinde konumlanmış olsa da bölgede yaşayan insanların, kentten yalıtılmış bir topluluk olarak kalmaları dikkat çekicidir. İşsizlik, yoksulluk ve yalıtılmışlık arasındaki döngü, toplumun birçok kesiminin bu bölgelere yönelik empati kurma arzusunun eksikliği ve güvenlik merkezli yaklaşımın güçlenmesi ile daha da sağlamlaşmaktadır. Öyle ki, bu döngü kuşaktan kuşağa aktarılmaktadır (27).

Çalışmanın tüm sonuçları, suça sürüklenmenin yüksek olduğu bölgelerin sosyoekonomik yapısına yönelik literatürden edinilen bilgilerle birlikte değerlendirildiğinde çocukların suça sürüklenmesinin, sosyoekonomik düzeyi düşük bölgelerde/mahallelerde ve mal varlığına karşı suçlarda yoğunlaştığı görülmektedir. Araştırmanın bulgularının, suç önleme çalışmalarına yardımcı olabilmesi temenni edilmektedir.

Çocukların suça sürüklenmesinde pek çok faktörün söz konusu olması suça sürüklenmenin önlenmesinin ceza adalet sisteminin sunmuş olduğu ve sadece çocuğa odaklanan yollarla mümkün olmadığının da bir göstergesidir (10). Etkin bir önleme ancak tüm toplumun, sosyal kurumların ve siyasal otoritenin yüksek sorumluluk bilinci ile davranması ve çevresel faktörlerin daha çok dikkate alınması ile mümkün olabilir (8).

Elde ettiğimiz bulgular çocukların suça sürüklenmesinin önlenmesinde, suç oluştuktan sonra değil, oluşmadan önce gerekli müdahalelerin yapılması gerektiği görüşünü destekler niteliktedir. (10). Tonry ve Farrington (17) yaptıkları çalışmalar ile çocukların suça sürüklenmesi- 
nin önlenmesinde gelişimsel suç önleme programlarının önemi üzerinde durmaktadır. Bu programlar, çocuğun suça sürüklenmesinde aile, kişilik özellikleri, akran grubu ve yaşanılan yer gibi koruyucu ve risk faktörlerinin doğru bir şekilde tespit edilmesinin yanı sıra sistematik bir şekilde etkin müdahaleler ile koruyucu faktörlerin güçlendirilmesini ve risk faktörlerinin etkisinin azaltılmasını içermektedir. Bu programların, diğer suç önleme yöntemlerinden en önemli farkı kişilerin yıllar içerisinde düzenli olarak takip edildiği uzunlamasına çalışmalarla desteklenmesidir (17).

Çalışmanın sonuçları göz önünde bulundurulduğunda, SSÇ'ların yoğunlukla ikamet ettiği yerleşim birimlerine suçu önleme kapsamında, standart programlardan ziyade o bölge/ilçe/mahallenin dinamikleri ve ihtiyaçları çerçevesinde özelleşmiş programlar oluşturularak uygulanmasının önemi karşımıza çıkmaktadır. Ayrıca söz konusu programlar, çocuklar her yaş döneminde farklı bilişsel, duygusal, fiziksel ve sosyal aşamalardan geçtikleri göz önüne alınarak düzenlenmelidir. Suç önleme programlarının geliştirilmesi esnasında multidisipliner bir uzman kadrosunun yanı sira yerel belediyeler, sivil toplum kuruluşları ve en önemlisi o bölgede yaşayan insanlar ve en önemlisi çocuklar, hem hazırlanma hem de uygulama aşamasına mutlaka dâhil edilmelidir. Çocuk ve ailelerin yaşam kalitesini artırma konusunda dünyadaki örneklere bakıldığında, yerel yönetimlerin merkezi yönetimlere göre daha aktif rol oynadığı görülmektedir (28). Dahası, uzunlamasına çalışmalarla bu programların daha etkin hale getirilmesi hedeflenmelidir.

\section{Kaynaklar}

1. UNICEF Türkiye. Sosyal Çalışma Görevlileri için Eğitim Kitabı. 1. Baskı, Ankara, 2013: 17.

2. Çoşar Y. Kentleşen Türkiye'de çocuk suçluluğu. TBB Dergisi 2005;56:281-327.

3. Altunbaş U. İstanbul'da suça sürüklenen çocukların yaşadığı mahallelerde arazi değerleri. Planlama 2014;24(3):182-188. doi: 10.5505/planlama.2014.21939

4. Danış MZ, Şahbikan İ. Suça sürüklenmiş çocukların yeniden toplumsallaşma sürecinde ve insan hakları bağlamında sosyal hizmet yaklaşımlarının yeri ve önemi. Tarih Okulu Dergisi (TOD) 2014;18:627-651. doi: $10.14225 /$ Joh529

5. Fowler E. The Encyclopedia of Criminology and Criminal Justice. 1st Ed. Albanese JS, editor. John Wiley \& Sons, Inc.; 2014. doi: 10.1002/9781118517383. wbeccj515
6. Kirk AR. Predictors of juvenile recidivism: Analysis of multiple factors associated with juvenile delinquency [dissertation]. Athens, Georgia: The University of Georgia; 2012.

7. Kamer VK. Mükerrir suçluluğa sosyolojik bakış. Adalet Dergisi 2013;45:1-16.

8. Top K. Suça itilen çocuklarda akıl ve ruh sağlı̆ğ problemlerinin yaygınlığ 1 ve çeşitliliği [unpublished master's thesis]. [İstanbul]: Maltepe Üniversitesi, Sosyal Bilimler Enstitüsü; 2010.

9. Bayındır N, Özel A, Köksal E. Çocuk suçluluğu demografisi: Kütahya şehri örneği. Polis Bilimleri Dergisi 2007;9(1-4):95-108.

10. Topçuoğlu T. Çocuk suçluluğu ve gelişimsel (riskodakl1) suç önleme. KMÜ Sosyal ve Ekonomik Araştırmalar Dergisi 2014;16:217-226.

11. Güvenlik birimine suça sürüklenme ile gelen veya getirilen çocuk sayısı url: http://www.tuik.gov.tr/PreIstatistikTablo.do?istab_id $=1623$

12. Bradshaw W, Roseborough D, Umbreit MS. The effect of victim offender mediation on juvenile offender recidivism: A meta-analysis. Conflict Resolution Quarterly 2006;24(1):87-98. doi: 10.1002/crq.159

13. Karasu MA. Türkiye'de kentleşme dinamiklerinin suça etkisi. Ankara Üniversitesi Hukuk Fakültesi Dergisi 2008;57(4):255-281.

14. Hancı İH, Aktaş EÖ, Akçiçek E. İç göçlerin çocuk suçluluğuna etkisi. Eğitim Dergisi, Ege Üniversitesi Edebiyat Fakültesi Yayını 1996;1:173-183.

15. Aksak P, Çalışkan V. Çanakkale kentinde mala karşı işlenen suçların coğrafi dağılış özelliklerinin incelenmesi. Marmara Coğrafya Dergisi 2010;22:245-275.

16. Grunwald HE, Lockwood B, Harris PW, Mennis $\mathrm{J}$. Influences of neighborhood context, individual history and parenting behavior on recidivism among juvenile offenders. J Youth Adolescence 2010;39:1067-1079. doi: 10.1007/s10964-0109518-5

17. Tonry M, Farrington DP. Strategic approaches to crime prevention. Crime \& Just. 1995;19:1-20. available at http://scholarship.law.umn.edu/faculty_articles/483.

18. Özden PP, Ün KH, İnce Y. Kentsel suç, mekân ve dönüşüm: Üsküdar ve Fatih ilçeleri üzerinden sorgulama. url: http://www.academia.edu/5706516/Kentsel_ Suç_Mekan_ve_Dönüşüm_Üsküdar_ve_Fatih_İlçeleri Üzerinden Sorgulama

19. Gürbüz M, Karabulut M. Adana Beş Ocak polis karakolu sorumluluk bölgesinde çocuk suçlarının coğrafi bilgi sistemleri ile haritalandırılması ve analizi. Ç.Ü. Sosyal Bilimler Enstitüsü Dergisi 2007;16(1):331-346.

20. Gönültaş BM, Hilal A. Çocuk suçluluğunda göç faktörü: Adana örneği. Adli Tip Dergisi 2012;26(3):156164. doi: $10.5505 /$ adlitip. 2012.86158 
21. Zeren C, Arslan MM, Yengil E, Karanfil R, Akçan R, Oksuz M. Socio-demograghic characteristics of juvenile delinquents in Turkey. The Journal of Forensic Psychiatry \& Psychology 2013;24(6):688-698. doi: 10.1080/14789949.2013.841972

22. Gönültaş BM. Adana ilinde mala ve şahsa karşı suç işleyen çocukların sosyodemografik özelliklerinin ortaya konulması [unpublished master's thesis]. [Adana]: Çukurova Üniversitesi, Sağlık Bilimler Enstitüsü; 2009.

23. Tamer H, Açıksarı Ö, Keten A, Karanfil R, Avşar A. Kahramanmaraş ilinde suça sürüklenen çocukların sosyodemografik özellikleri. Adli Tıp Dergisi 2014;28(2):115-120. doi:10.5505/adlitip.2014.08760

24. Fırat S, İltaş Y, Gülmen MK. Adana'da suça sürüklenen çocukların sosyodemografik özellikleri.
Adli Tıp Bülteni 2016;21(2):86-92. doi: 10.17986/ blm.2016220393

25. Kurtuluş A, Salman N, Günbet G, Boz B, Cenger CD, Acar K. Denizli ilinde 12-15 yaş arasındaki suça sürüklenen çocukların sosyodemografik özellikleri. Pamukkale Tıp Dergisi 2009;2(1):8-14.

26. Tokdemir M, Kafadar H, Türkoğlu A, Düzer S, Şimşek C. 2005-2007 yılları arasında Elazı̆̆ ilindeki suça itilmiş çocukların sosyodemografik özellikleri. e-Journal of New World Sciences Academy 2008;3(4):154-158.

27. Baloğlu F. Kentsel yoksulluk: İstanbul'dan küçük bir kesit. Sosyoloji Konferansları Dergisi 2005;31:231249.

28. Çakırer-Özservet Y. Çocuk dostu belediyecilik. İller ve Belediyeler Dergisi 2015;802:38-43. 